\title{
Within-patient emergence of the influenza A(H1N1) pdm09 HA1 222G variant and clear association with severe disease, Norway
}

R Rykkvin ${ }^{1}$, A Kilander (anette.kilander@fhi.no) ${ }^{1}$, S G Dudman ${ }^{1}, 0$ Hungnes ${ }^{1}$

1. Department of Virology, Norwegian Institute of Public Health, Oslo, Norway

Citation style for this article:

Rykkvin R, Kilander A, Dudman SG, Hungnes O. Within-patient emergence of the influenza $A\left(\mathrm{H}_{1} \mathrm{~N}_{1}\right)$ pdmog HA1 $222 \mathrm{G}$ variant and clear association with severe disease, Norway. Euro Surveill. 2013;18(3):pii=20369. Available online: http://www.eurosurveillance.org/ViewArticle.aspx?Articleld=20369

Article submitted on 29 June 2012 / published on 17 January 2013

The association between a particular mutation in the HA1 subunit of the influenza virus haemagglutinin, D222G, and severe and fatal disease in cases of influenza $A\left(\mathrm{H}_{1} \mathrm{~N}_{1}\right)$ pdmog in Norway during the 2009 pandemic was investigated using pyrosequencing. The prevalence of the variant among fatal cases was 8/26 and among severe non-fatal cases 5/52. No D222G mutations were found among the 381 mild cases. This difference could not be attributed to sampling differences, such as body location of sampling, or duration of illness. In cases with mutant virus where clinical specimens from different days of illness were available, transition from wild-type to mutant virus was commonly observed (4/5), indicating that the mutant virus emerged sporadically in individual patients. In patients with paired samples from both the upper and lower respiratory tract $(n=8)$, the same viral genotypes were detected in both locations. In most of the $\mathrm{D} 222 \mathrm{G}$ cases (11/13), the mutant virus was found as a quasispecies.

\section{Introduction}

Infection with the pandemic influenza $A\left(\mathrm{H}_{1} \mathrm{~N}_{1}\right)$ virus that emerged in 2009 led to mild disease in the vast majority of cases; however, there was also an unusual occurrence of viral pneumonia, severe disease and death in younger age groups than commonly observed for seasonal influenza [1]. In a large proportion of severe cases, conditions predisposing for severe disease have been identified [2] and host factors therefore appear to strongly influence the clinical outcome of infection. On the other hand, this novel virus of zoonotic origin differed from the previous seasonal $A\left(\mathrm{H}_{1} \mathrm{~N}_{1}\right)$ virus in the resulting disease profile; thus, viral determinants of pathogenicity must also be involved - e.g. it has been shown to be more pneumotropic than seasonal $A\left(\mathrm{H}_{1} \mathrm{~N}_{1}\right)$ virus in a ferret model [3]. It is important to understand better what viral and host-related factors determine the observed dichotomous pathogenicity profile.

The first cases of influenza $\mathrm{A}\left(\mathrm{H}_{1} \mathrm{~N}_{1}\right)$ pdmog virus infection in Norway were recorded in early May 2009, shortly after emergence in Mexico, but cases were few and scattered across the country until mid-summer. A limited influenza epidemic took place in late July/early August, followed by a comparatively calm period leading up to a major epidemic that surpassed all previous peaks recorded in the current surveillance system. The epidemic reached its highest point in early November and by the end of 2009 , it had mostly subsided.

As part of the intensified surveillance carried out during the 2009 influenza pandemic, the national reference laboratory for human influenza at the Norwegian Institute of Public Health received a large number of respiratory specimens from confirmed and possible cases of influenza $\mathrm{A}\left(\mathrm{H}_{1} \mathrm{~N}_{1}\right)$ pdmog. In late November 2009, we noticed that a particular amino acid substitution - aspartic acid (D) to glycine (G) in the viral haemagglutinin (HA) glycoprotein subunit $\mathrm{HA}_{1}$ at position 222 (D222G) - appeared in fatal cases, while we did not find it in the numerous mild cases analysed. Realising that a similar pattern seemed to be taking place in the Ukraine (R. Daniels, personal communication, November 2009) and given that the mutation had been shown to influence viral receptor specificity in another influenza $A\left(\mathrm{H}_{1} \mathrm{~N}_{1}\right)$ virus [4], it was decided to notify international public health authorities and other national authorities about this possible pathogenicity determinant, to expedite assessment of it [5]. A preliminary review in January 2010 of D222G amino acid substitution in the $\mathrm{HA}$ of influenza $\mathrm{A}\left(\mathrm{H}_{1} \mathrm{~N}_{1}\right)$ pdmog viruses from the World Health Organization (WHO) stated that mutations, including those leading to the D222G substitution in the HA, had appeared sporadically since the first emergence of influenza $A\left(\mathrm{H}_{1} \mathrm{~N}_{1}\right)$ pdmog viruses, and that the substitutions in HA had been reported in viruses obtained from cases of mild to severe to fatal illnesses but that such viruses had neither formed distinct phylogenetic clustering nor been associated with consistent changes in virus antigenicity [6].

Since the first account of our findings in Norway [7], investigations into the occurrence of this mutation resulted in an increasing number of reports [8-28]. While the prevalence of this mutation varied between 
the reporting countries, in most studies, the $222 \mathrm{G}$ mutation is primarily found in severe and fatal cases. One of the first larger studies came from a group in Hong Kong, who analysed this amino acid position in severe and non-severe cases of influenza $A\left(\mathrm{H}_{1} \mathrm{~N}_{1}\right)$ pdmog [13]. Nine (4.1\%) of 219 severe or fatal cases of pandemic influenza had the mutation, in contrast to none of 239 non-severe cases.

Data from these reports indicated that the D222G mutation was absent or uncommon in viruses that were in sustained circulation. However, one case of transmission of a $222 \mathrm{G}$ virus was reported [9], but the transmitted virus in this case had acquired an additional mutation that may have influenced receptor binding characteristics.

To further investigate the sporadic occurrence of the $222 \mathrm{G}$ mutant influenza virus, we performed a more indepth analysis of an expanded data set. Our original data set [7] included 266 cases, while the expanded set comprised 462 cases. The present study included assessment of the majority of the fatal cases in Norway, as well as of a larger number of samples from severe non-fatal and mild cases collected throughout the pandemic.

We studied the prevalence of HA1 222 mutations within different clinical outcome groups, in serially collected specimens, in upper versus lower respiratory tract and in early versus late specimens. We also analysed age and sex distribution and examined the characteristics of the fatal cases.

We further compared the mutant viruses phylogenetically, looked for the presence of mutant quasispecies and oseltamivir resistance.

\section{Methods}

\section{Data and clinical materials}

As part of the intensified surveillance instigated in response to the emergence of influenza $A\left(\mathrm{H}_{1} \mathrm{~N}_{1}\right)$ pdmog in April 2009, virus-containing specimens from all parts of the country were received in the Norwegian Institute of Public Health, which serves as the National Influenza Centre in Norway. A total of 15 medical microbiology laboratories submitted specimens containing influenza virus (original specimens, nucleic acid preparations from original specimens or virus isolates) to the National Influenza Centre for further characterisation. Most of these patient specimens originated from primary care clinics; the remainder were from hospitals.

Each laboratory sent a maximum of five specimens each week plus any specimens from patients with severe disease, suspicion of antiviral resistance or other special circumstances such as suspected vaccine failure. In addition, intensive care and fatal cases remained notifiable to the Norwegian Institute of Public Health throughout the pandemic and we actively solicited materials from microbiology and pathology laboratories that were in possession of specimens from these cases. Together, these collection schemes enabled us to obtain specimens from nearly all the recorded fatal influenza $A\left(\mathrm{H}_{1} \mathrm{~N}_{1}\right)$ pdmog cases in Norway as well as a large number of severe and mild cases. Patient information relevant for this study was obtained primarily from the patient referral forms that came with the specimens, supplemented with information gathered in the notification of severe and fatal cases and, in a few cases, from direct contact with clinicians who cared for the patient. Cases were assigned to clinical outcome groups by a medical specialist, according to WHO guidance criteria [2]. Briefly, the criteria for complicated/severe influenza included: clinical and/or radiological signs of lower respiratory tract disease, central nervous system involvement, severe dehydration, secondary complications (renal failure, multiorgan failure, septic shock, rhabdomyolysis, myocarditis), exacerbation of underlying chronic disease or signs and symptoms of progressive influenza disease. The criteria were modified as follows: hospital admission in itself did not lead to classification as severe influenza, without additional evidence of complicated disease. This modification was necessary due to a low threshold for hospitalisation of patients during parts of the pandemic. Furthermore, sustained virus replication in itself was not regarded as evidence of severe influenza. From the available specimens, we picked all the specimens from fatal and ICU cases as well as a large subset of specimens from the other cases, making sure that viruses from all parts of Norway and from the entire first period of $A\left(\mathrm{H}_{1} \mathrm{~N}_{1}\right)$ pdmog virus circulation in the country (May 2009-January 2010) were well represented. The selected specimens were sequenced with regard to the codon encoding amino acid 222 of the $\mathrm{HA}_{1}$ subunit. Only cases where the HA1 222 genotype could be ascertained in the original specimen were included in the study.

\section{Detection of HA1 222 mutations \\ at nucleic acid level}

Initially, mutations were detected through conventional (Sanger) cycle sequencing of reverse transcription-polymerase chain reaction (RT-PCR) amplicons obtained from viral RNA from virus isolates and primary specimens.

Viral RNA was extracted using a total nucleic acid extraction kit in the MagNA Pure LC System (Roche Diagnostics, Mannheim, Germany). In general, a modification of the full genome sequencing protocol provided by the United States Centers for Disease Control and Prevention [28] was used for virus isolates, whereas sequencing of the amplicon from a more sensitive RT-PCR [30] was used for many of the primary specimens.

As soon as we became aware of the possible importance of the mutation, a pyrosequencing assay was designed and used. Briefly, a 110-nucleotide amplicon 


\section{FIGURE 1}

Phylogenetic reconstruction of influenza A(H1N1)pdm09 haemagglutinin gene (HA1), Norway 2009/10, showing the distribution of $222 \mathrm{G}$ viruses across the phylogeny

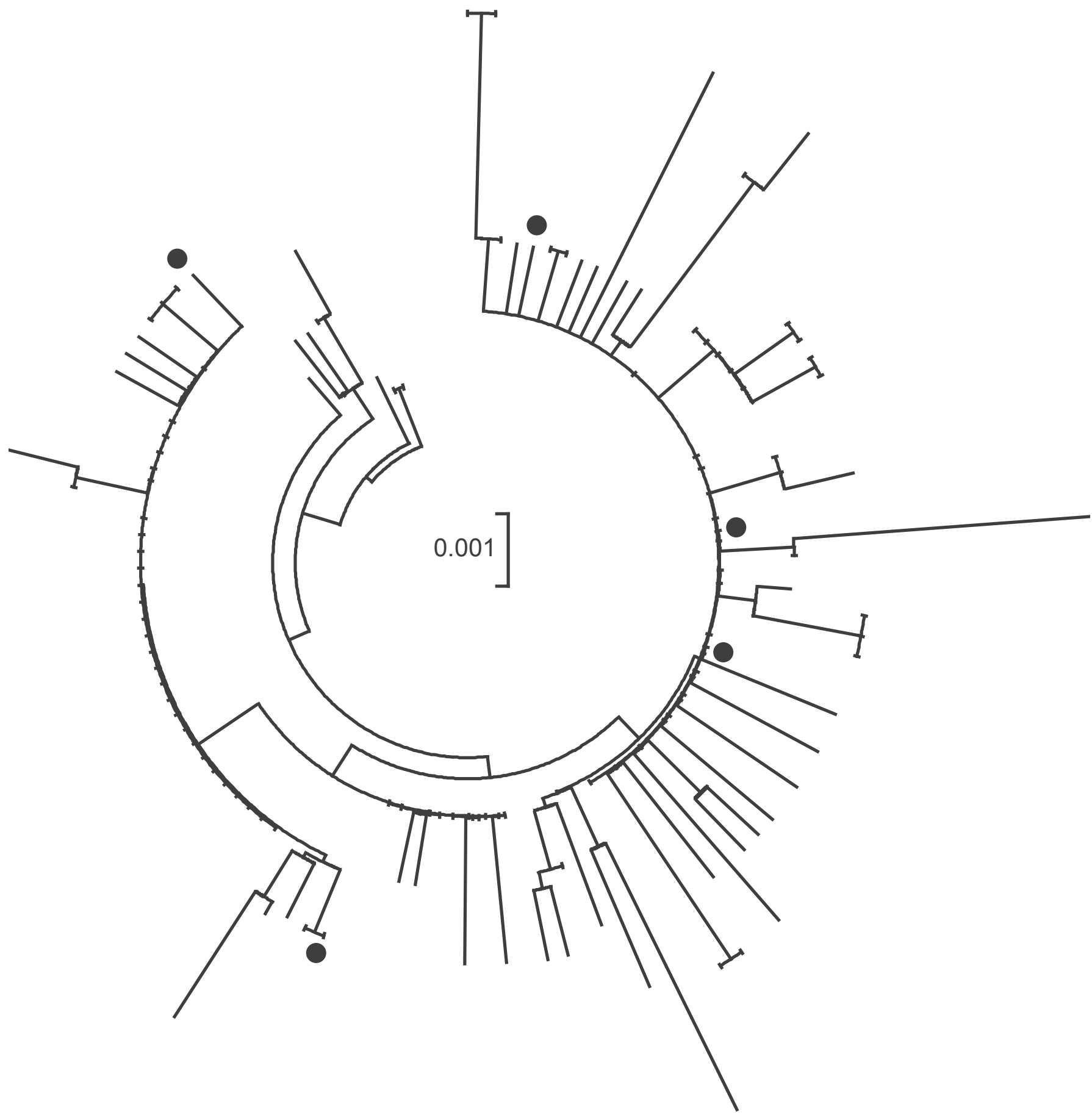

Viruses harbouring $222 \mathrm{G}$ are marked with solid circles. The entire coding region of the HA1 subunit was analysed. The codon for amino acid 222 was excluded for this analysis, in order to investigate how $222 \mathrm{G}$ mutants were otherwise related. 
TABLE 1

Risk factors for severe illness in fatal cases of influenza A(H1N1)pdm09 with available haemagglutinin gene (HA1) 222 genotype, Norway, 2009/10 (n=26)

\begin{tabular}{|l|c|}
\hline Risk factors for severe disease & Number of cases \\
\hline Presence of risk factors & 4 \\
\hline None & 21 \\
\hline One or more & 1 \\
\hline Data unavailable & \\
\hline Individual risk factors & \\
\hline Chronic respiratory disease & 4 \\
\hline Chronic heart disease & 7 \\
\hline Chronic renal or hepatic disease & 0 \\
\hline Diabetes & 2 \\
\hline Pregnancy & 1 \\
\hline Obesity & 3 \\
\hline Immunosuppression & 3 \\
\hline Chronic neurological disease or injury & 3 \\
\hline Other & 7 \\
\hline
\end{tabular}

a Each patient may have several risk factors.

b Obesity: for one of these patients, a body mass index (BMI) of >40 was reported. The other two were reported as 'obese' or 'adipose', with no BMI given.

encompassing the region of the HA gene which encodes amino acid 222 was generated from $5 \mu \mathrm{l}$ specimen RNA combined with each of primers pyro- $\mathrm{H}_{1}$ forward: 5'AGTTCAAGCCGGAAATAGCA-3' and pyro- $\mathrm{H}_{1}$ reverse: 5'-biotin-TTTCCAGTTGCTTCGAATGTT-3' and reagents from the SuperScript III One-Step RT-PCR System with Platinum Taq High Fidelity kit (Invitrogen) in a $25 \mu \mathrm{l}$ reaction and subjected to the following cycling conditions: $30 \mathrm{~min}$. at $50{ }^{\circ} \mathrm{C}, 2 \mathrm{~min}$. at $94{ }^{\circ} \mathrm{C} ; 45$ cycles of 15 sec. denaturation at $94{ }^{\circ} \mathrm{C}, 30 \mathrm{sec}$. annealing at $55^{\circ} \mathrm{C}$ and $1 \mathrm{~min}$. extension at $68{ }^{\circ} \mathrm{C}$; finally, $5 \mathrm{~min}$. at $68^{\circ} \mathrm{C}$ for final extension.

The pyrosequencing reactions were performed as previously described [29] using a residue-specific sequencing primer (5'-AGCAATAAGACCCAAAGTGAGG-3').

The sequenced region begins at nucleotide 747 in the full-length sequence of the viral RNA segment 4 , where nucleotides 747-749 encode HA1 amino acid 222. The most common wild-type codon in this position is GAT, which encodes aspartic acid (D). The GAA codon encodes glutamic acid (E), while GGT (or GGA) gives glycine $(G)$. Mutation of $G$ to $A$ in the first position of the GAT codon gives asparagine $(\mathrm{N})$.

The viruses were also analysed for oseltamivir susceptibility by detecting the $\mathrm{H} 274 \mathrm{Y}$ mutation by sequence analysis, through either a pyrosequencing assay targeting the relevant single-point mutation [31] or through full- or partial-length cycle sequencing of the coding region for the viral neuraminidase.

\section{Phylogenetic analysis}

Phylogenetic analysis was performed on aligned sequences comprising the entire coding region of the HA1 subunit. Kimura 2-parameter corrected pairwise distances between manually aligned sequences were computed using the PHYLIP [32] program DNADIST, and the phylogenetic tree inferred using NEIGHBOR. The resulting tree was visualised using MEGA version 5.0 [33].

\section{Statistical analysis}

Statistical analysis was undertaken using PASW 17, version 17.02 (SPSS Inc., Chicago, United States). Descriptive statistics were calculated as medians with upper and lower range or as means with $95 \%$ confidence intervals. All hypothesis tests were two-tailed and statistical significance was assessed at the 0.05 level. Comparisons of categorical variables were performed using Fisher's exact test and comparisons of non-normal continuous distributions using the MannWhitney U test.

\section{Results}

In total, 462 influenza $A\left(\mathrm{H}_{1} \mathrm{~N}_{1}\right)$ pdmog cases where the HA1 222 genotype could be ascertained in the primary specimen were included in the study. A large proportion of the isolated viruses were sent to the WHO Collaborative Centre for Reference and Research on influenza in the National Institute for Medical Research, Mill Hill, United Kingdom, for further characterisation. No changes in virus antigenicity were found (data not shown). We did not find the $\mathrm{H} 274 \mathrm{Y}$ mutation, commonly associated with oseltamivir resistance, in any of the viruses in this study. In phylogenetic analysis of the HA1 coding region of Norwegian viruses (Figure 1), the five $222 \mathrm{G}$ harbouring viruses for which we could ascertain the full HA1 coding sequence occurred on different branches of the tree, showing that they did not form a distinct genetic cluster. This is in good agreement with the fact that the cases with $222 \mathrm{G}$ viruses occurred sporadically across Norway, at different times during the period of widespread virus circulation.

Of the 462 cases included in the analysis, 381 had mild disease, 52 had severe disease but were non-fatal and 26 were fatal (clinical outcome was unknown for three cases).

The median age of the cases with mild disease included was 20 years (range: $0-87$ ), for the non-fatal cases with severe disease 27 years (range: 0-66 years) and for the fatal cases 38 years (range: 0-71). Among all 462 cases, 225 (49\%) were men and 237 (51\%) were women. The proportion of men versus women was similar for mild cases ( $48 \%$ vs $52 \%$ ), severe non-fatal cases ( $52 \%$ vs $48 \%$ ) and fatal cases ( $46 \%$ vs $54 \%$ ). Of the 13 cases with $222 \mathrm{G}$ virus, eight were men and five were women: these proportions (62\% vs $38 \%$ ) were not 
Prevalence of haemagglutinin gene (HA1) 222 genotypes by clinical outcome (mild, severe non-fatal, fatal disease), influenza A(H1N1)pdm09 cases, Norway, 2009/10 (n=462)

\begin{tabular}{|l|c|c|c|c|c|c|}
\hline \multirow{2}{*}{$\begin{array}{l}\text { HA1 } \\
\text { genotype }\end{array}$} & $\begin{array}{c}\text { Mild } \\
\mathrm{n}(\%)\end{array}$ & $\begin{array}{c}\text { Severe non-fatal } \\
\mathrm{n}(\%)\end{array}$ & $\begin{array}{c}\text { Fatal } \\
\mathrm{n}(\%)\end{array}$ & $\begin{array}{c}\text { Severe including fatal } \\
\mathrm{n}(\%)\end{array}$ & $\begin{array}{c}\text { Unknown } \\
\mathrm{n}(\%)\end{array}$ & $\begin{array}{c}\text { Total } \\
\mathrm{n}(\%)\end{array}$ \\
\hline 222D wild type & $329(86.4)$ & $40(76.9)$ & $15(57.7)$ & $55(70.5)$ & $2(66.7)$ & $386(83.5)$ \\
\hline $222 \mathrm{G}$ & $\mathrm{o}(0)$ & $5(9.6)$ & $8(30.8)$ & $13(16.7)$ & $0(0)$ & $13(2.8)$ \\
\hline $222 \mathrm{E}$ & $51(13.4)$ & $5(9.6)$ & $2(7.7)$ & $7(9.0)$ & $1(33.3)$ & $59(12.8)$ \\
\hline $222 \mathrm{~N}$ & $1(0.3)$ & $2(3.8)$ & $1(3.8)^{\mathrm{b}}$ & $3(3.8)^{\mathrm{b}}$ & $0(0)$ & $4(0.9)^{\mathrm{b}}$ \\
\hline Total & $\mathbf{3 8 1 ( 1 0 0 )}$ & $\mathbf{5 2 ( 1 0 0 )}$ & $\mathbf{2 6 ( 1 0 0 )}$ & $\mathbf{7 8 ( 1 0 0 )}$ & $\mathbf{3 ( 1 0 0 )}$ & $462(\mathbf{1 0 0})$ \\
\hline
\end{tabular}

a Severe non-fatal and fatal cases are shown separately and jointly.

b Additionally, one fatal $222 \mathrm{G}$ case harboured $222 \mathrm{~N}$ virus as a quasispecies.

significantly different from those cases with non-222G viruses $(48 \%$ vs $52 \%, n=449)(p=0.41$, Fisher's exact test).

In the total data set, 13 cases harboured $222 \mathrm{G}$ viruses, $222 \mathrm{E}$ occurred in 59 cases and $222 \mathrm{~N}$ in four cases (one additional case contained both $222 \mathrm{G}$ and $222 \mathrm{~N}$ quasispecies, and was classified as the former). In 386 cases we detected only wild-type $222 \mathrm{D}$ viruses (Table 2). The presence of mutants found in the pyrosequencing assay was verified by conventional sequencing in all 10 cases where sequencing of primary samples was possible.

In order to avoid bias stemming from preferential testing of severe cases in our samples, the prevalence of different genetic variants was recorded within each clinical outcome group, instead of the other way round. Among the 26 fatal cases, eight harboured the $222 \mathrm{G}$ virus at some time during the course of infection. The corresponding proportion for severe non-fatal cases was 5/52 (10\%) while none was found in 381 analysed cases with mild disease. The proportions in fatal as well as in severe non-fatal cases were higher than in mild cases ( $p<0.0005)$. Furthermore, the higher frequency in fatal cases compared with severe non-fatal cases was also statistically significant $(p=0.026$, Fisher's exact test).

One specimen from a fatal case contained both $222 \mathrm{G}$ and $222 \mathrm{~N}$ viruses in addition to wild-type $222 \mathrm{D}$. Two of the $222 \mathrm{G}$ mutants had adenine in the third codon position and thus are likely to have arisen from $222 \mathrm{E}$ viruses. The prevalence of the $222 \mathrm{E}$ variant showed no significant difference between the various clinical outcome groups, and this variant represents a circulating clade with no apparent effect on virulence [9.10].

In the majority of $222 \mathrm{G}$ cases $(11 / 13)$, the $222 \mathrm{G}$ mutants occurred as quasispecies, typically with wild type 222D sequence being more frequent (exemplified in Figure 2). The proportion of mutant virus in mixed populations as estimated by pyrosequencing tended to be less than 50\% (range: $18-59$ ). In all 10 cases analysed by both conventional sequencing and pyrosequencing, these mixtures were also evident as double peaks in conventional sequencing (see example in Figure 2).

In eight cases, paired specimens from upper and lower respiratory tract were available for analysis. Six of these cases had a fatal outcome. These specimen pairs were collected on the same day from the same patients. Upper/lower respiratory tract specimens from the same case but collected on different days were not considered as pairs in this analysis. Both 222D and $222 \mathrm{G}$ viruses were found in the samples, but in all eight pairs, the HA1 222 genotype in the upper and lower respiratory tract samples matched (Table 3).

\section{TABLE 3}

Prevalence of haemagglutinin gene (HA1) 222 genotypes in paired ${ }^{\mathrm{a}}$ upper and lower respiratory tract samples, influenza A(H1N1)pdm09 cases, Norway, 2009/10 ( $\mathrm{n}=8)$

\begin{tabular}{|c|c|c|}
\hline \multicolumn{2}{|c|}{ HA1 222 genotype } & \multirow{2}{*}{$\begin{array}{c}\text { Number } \\
\text { of patients }\end{array}$} \\
\cline { 1 - 2 } $\begin{array}{c}\text { Upper respiratory } \\
\text { tract sample }\end{array}$ & $\begin{array}{c}\text { Lower respiratory } \\
\text { tract sample }^{\mathrm{b}}\end{array}$ & 5 \\
\hline $222 \mathrm{D}$ & $222 \mathrm{D}$ & 2 \\
\hline $222 \mathrm{G}$ & $222 \mathrm{G}$ & 1 \\
\hline $222 \mathrm{D} / \mathrm{G} \mathrm{mix}$ & $222 \mathrm{D} / \mathrm{G} \mathrm{mix}$ & \\
\hline
\end{tabular}

The samples were collected from the same patients on the same day.

b Upper respiratory tract samples included nasopharyngeal swabs/aspirates, nasal swabs and throat swabs.

Lower respiratory tract samples included tracheal aspirates and lung autopsy material. 


\section{FIGURE 2}

Detection of D222G mutations in the haemagglutinin gene (HA1) using pyro- and Sanger sequencing, influenza A(H1N1) pdm09 cases, Norway 2009/10

A

D222

(wild type)

B

$\mathrm{D} 222(\mathrm{D}) / \mathrm{G}$

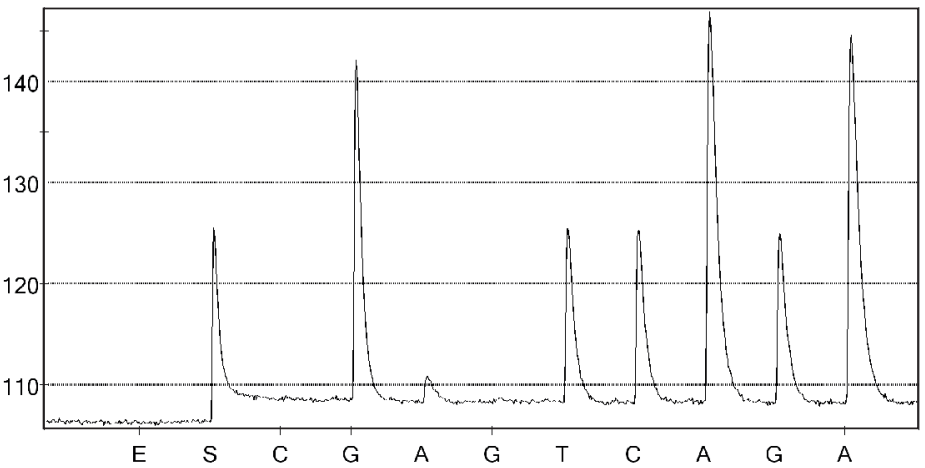

C

E222G

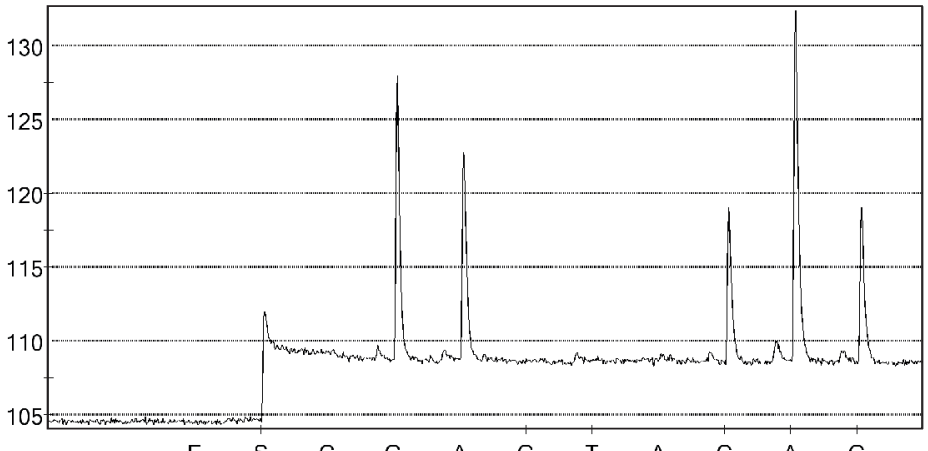

E S $C \quad G \quad A \quad G \quad T \quad A-C \quad A \quad G$

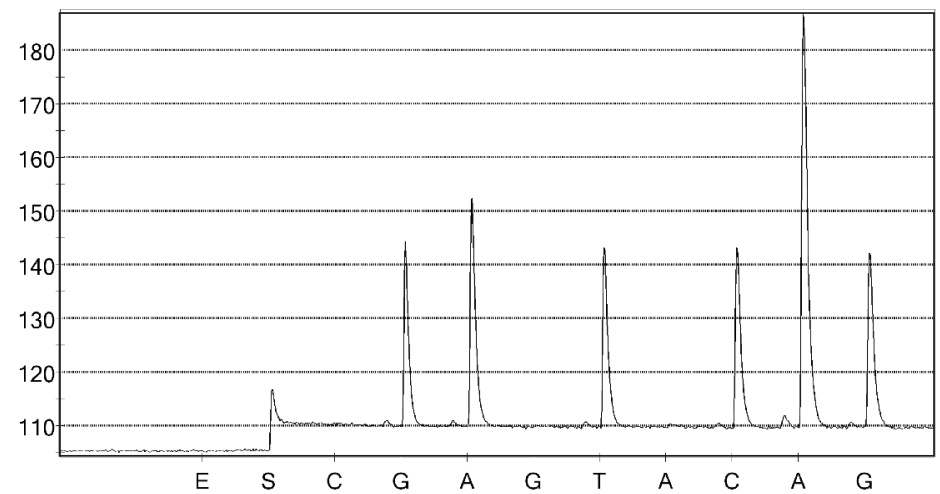

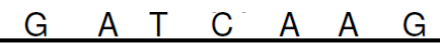
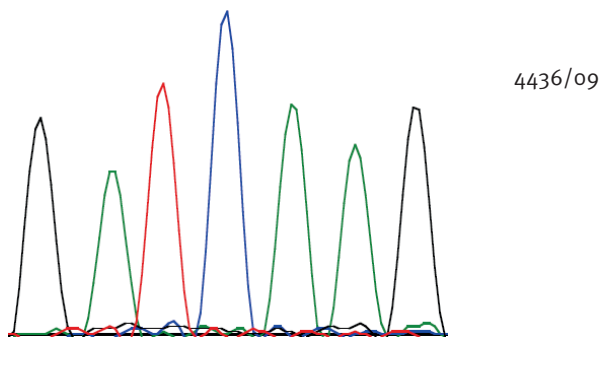

$4436 / 09$

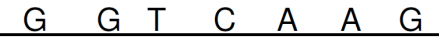

$3487 / 09$
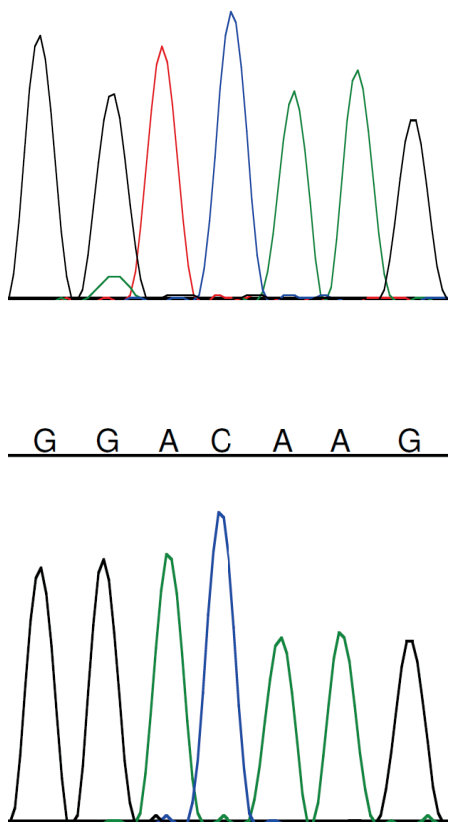

$3206 / 09$
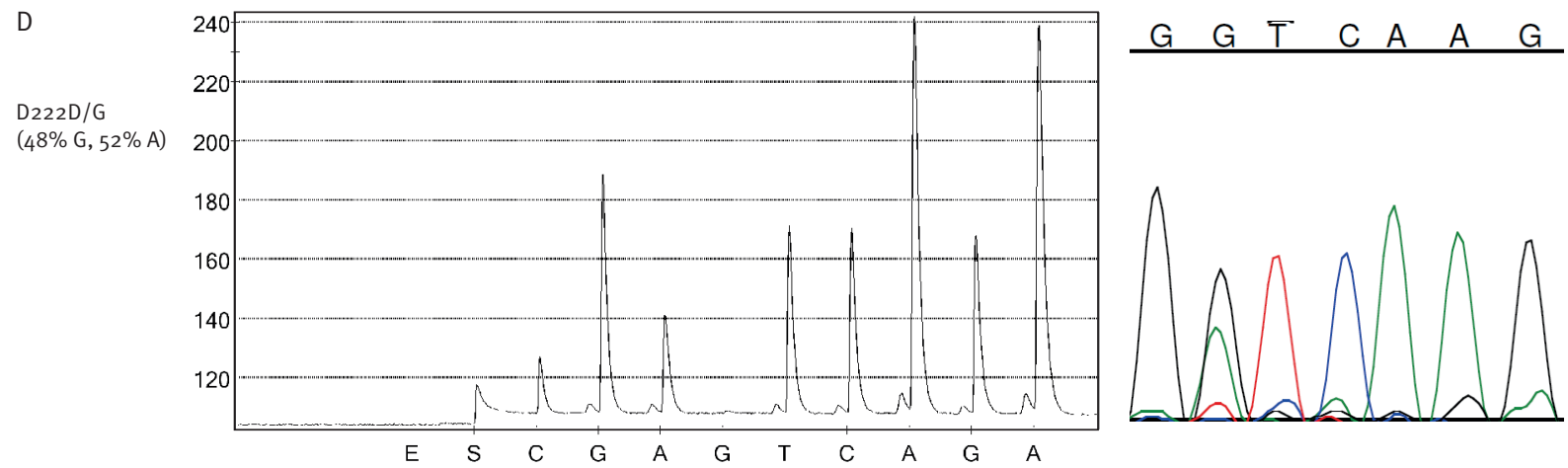

$4823 / 09$

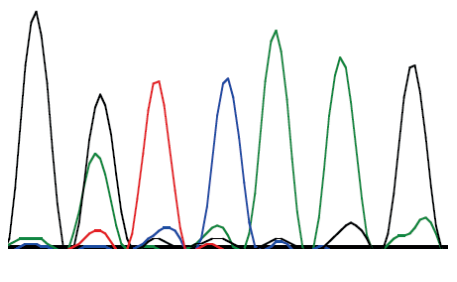

Sequence chromatograms at position 222 of influenza $A\left(\mathrm{H}_{1} \mathrm{~N}_{1}\right)$ pdmog virus $\mathrm{HA}_{1}$ gene region derived from four primary clinical samples collected in Norway 2009/10 (4436/09, 3487/09, 3206/09, 4823/09). Chromatograms from pyrosequencing are shown on the left-hand side, those from Sanger sequencing are on the right), illustrating wild-type sequence (panel A), and mutations (panels B-D). In panel D, polymorphism at the 222 codon, with $48 \% \mathrm{G}$ and $52 \% \mathrm{~A}$, is illustrated. 


\section{FIGURE 3}

Detection of mutations in the haemagglutinin gene (HA1) through the course of illness in influenza A(H1N1)pdm09 cases with serial samples, Norway, 2009/10

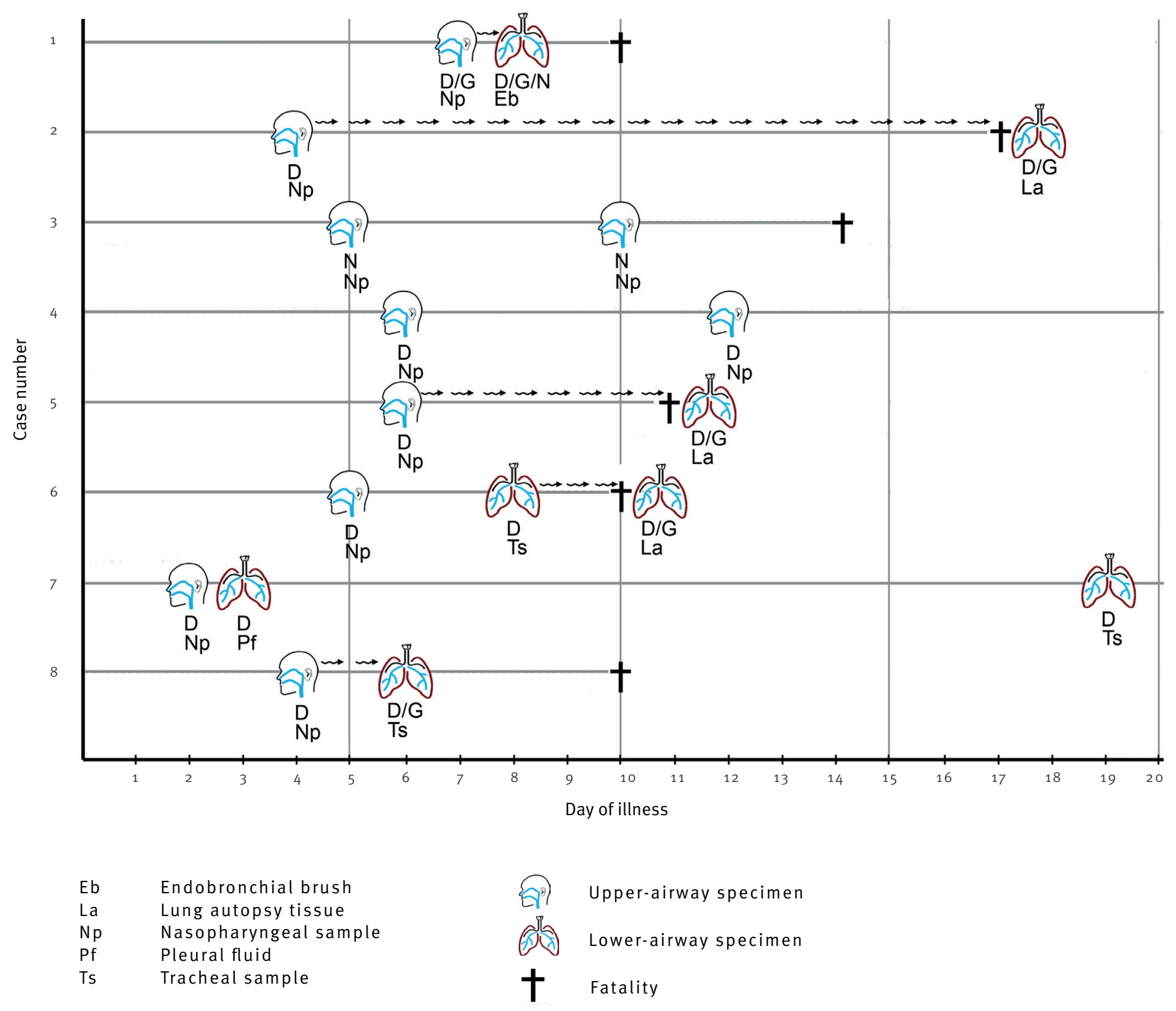

Amino acid substitution - D: aspartic acid; G: glycine; N: asparagine.

Genotype changes are shown by arrows. 
Of the 13 patients with $222 \mathrm{G}$ mutant viruses, we had two or more serial samples available for five (Figure 3). In four of these patients (Cases 2, 5, 6 and 8 in Figure 3), we found only $222 \mathrm{D}$ wild type viruses in samples preceding detection of $222 \mathrm{G}$ mutant virus. In one patient (Case 1 in Figure 3), both available samples contained $222 \mathrm{G}$ mutant virus, but the samples were taken only one day apart, thus reducing the chance of finding differing genotypes. We also had serial samples for three additional non-222G patients (Cases 3, 4 and 7 in Figure 3) who exhibited the same genotype throughout the course of illness (either 222D or $222 \mathrm{~N}$ ).

The date of symptom onset was given for 263 cases: 212 mild, 33 severe non-fatal and 18 fatal. Specimens from the mild cases tended to be collected earlier in the course of illness (mean: 4.3 days after symptom onset; $95 \% \mathrm{Cl}: 3.7-4.9$ ) than specimens collected from all severe cases, including fatal cases (mean: 6.5 days; 95\% Cl: 5.2-7.8) ( $p=0.001$, Mann-Whitney U test). The proportion of $222 \mathrm{G}$ mutant viruses was higher in specimens collected late ( $\geq 8$ days after symptom onset) than in those collected early ( 8 days after symptom onset) $(p=0.001$, Fisher's exact test). Among specimens collected on day 8 or later, more than half were from mild cases (20/39) and there was still a significantly higher proportion of mutant virus in the severe cases, including those that were fatal $(6 / 19$ vs $0 / 20)(p=0.008$, Fisher's exact test) (Table 4).

As noted earlier, the median age of the cases included was higher among all the severe cases, including those that were fatal, than the mild cases ( $p<0.0005$, MannWhitney $\mathrm{U}$ test). The proportion of $222 \mathrm{G}$ mutant viruses was higher in specimens collected from patients aged 40 years or older than in younger patients $(8.2 \%(7 / 85)$ vs $1.6 \%$ (6/371), $p=0.004$, Fisher's exact test). However, among specimens collected from patients aged 40 years or above, there was still a significantly higher proportion of mutant viruses in the severe cases, including those that were fatal ( $p<0.0005$, Fisher's exact test, data not shown). Thus, the observed difference in $222 \mathrm{G}$ prevalence between the different clinical outcome groups is not due to age as a confounding factor.

\section{Discussion}

In the present study, we provide further epidemiological evidence of the association between the D222G mutation in $\mathrm{HA}_{1}$ of influenza $\mathrm{A}\left(\mathrm{H}_{1} \mathrm{~N}_{1}\right)$ pdmog virus and severe or fatal clinical course. Furthermore, we present evidence that the mutated viruses emerge in individual patients after the onset of illness and demonstrate the presence of mutant virus in both the upper and lower respiratory tract. We also address some potential biases that could conceivably confound the analysis.

The Norwegian cases of infection with $\mathrm{HA} 1222 \mathrm{G}$ genotype viruses have occurred sporadically and do not cluster epidemiologically or in phylogenetic analysis.

As observed by others, the D222G substitution has been observed to occur sporadically in the laboratory when specimens containing predominantly wildtype virus are subjected to virus isolation in eggs or mammalian cell lines $[6,13,35]$. We therefore based our analysis on viral sequences obtained from the primary clinical specimens.

The $222 \mathrm{G}$ viruses appear to be rare among circulating strains, but are still quite frequent in patients with severe disease, who are not epidemiologically linked. A likely explanation is that the presence of mutant viruses in these particular individuals experiencing severe disease is due to selective upgrowth of mutant genomes during infection. In all four $222 \mathrm{G}$ cases where we could analyse both early and late specimens, we observed a transition from wild-type to mutant virus, which lends support to the hypothesis that the presence of the mutant is due to sporadic emergence rather than widespread circulation.

In our analysis, we could not distinguish between upgrowth from a rare quasispecies, which may be present at inapparent levels in many more cases, and

\section{TABLE 4}

Prevalence of haemagglutinin gene (HA1) 222 genotypes in viruses from influenza A(H1N1)pdm09 cases sampled late in illness (day 8 or later), by clinical outcome, Norway, 2009/10 ( $n=39)$

\begin{tabular}{|l|c|c|c|c|}
\hline \multirow{2}{*}{$\begin{array}{l}\text { HA1 } \\
222 \\
\text { genotype }\end{array}$} & \multicolumn{4}{|c|}{ Specimens from cases taken on day 8 or later } \\
\cline { 2 - 5 } & $\begin{array}{c}\text { Mild } \\
\mathrm{n}(\%)\end{array}$ & $\begin{array}{c}\text { Severe } \\
\mathrm{n}(\%)\end{array}$ & $\begin{array}{c}\text { Fatal } \\
\mathrm{n}(\%)\end{array}$ & $\begin{array}{c}\text { Severe including fatal } \\
\mathrm{n}(\%)\end{array}$ \\
\hline $222 \mathrm{D}$ & $17(85)$ & $8(73)$ & $3(38)$ & $\begin{array}{c}\text { Total } \\
\mathrm{n}(\%)\end{array}$ \\
\hline $222 \mathrm{G}$ & $0(0)$ & $3(27)$ & $3(38)$ & $6(32)$ \\
\hline $222 \mathrm{E}$ & $3(15)$ & $0(0)$ & $1(13)$ & $1(5)$ \\
\hline $222 \mathrm{~N}$ & $0(0)$ & $0(0)$ & $1(13)$ & $1(5)$ \\
\hline Total & $\mathbf{2 0 ( 1 0 0 )}$ & $\mathbf{1 1 ( 1 0 0 )}$ & $\mathbf{8 ( 1 0 0 )}$ & $1(3)$ \\
\hline
\end{tabular}

\footnotetext{
a Severe non-fatal and fatal cases are shown separately and jointly.
} 
upgrowth from de novo mutation events. The $222 \mathrm{G}$ genotype appears to occur as sporadic mutations with no or little onward transmission, rather than through persistence as a circulating variant. If this is the case, the likelihood of finding mutant viruses is expected to increase during the course of infection. Conceivably, since the severe cases, including those that were fatal, tended to be sampled later in their course of illness than mild cases, the higher occurrence of mutations could alternatively be explained purely as a sampling artefact and not as a marker of virulence. But if the occurrence of the mutation was merely a function of time since infection, there should be no difference in the frequency of $222 \mathrm{G}$ mutant in specimens from mild versus severe cases, if taken equally late in infection. Our results show that the significant difference remained even when all early specimens were excluded: thus the difference in sampling day can be ruled out as an alternative explanation for the pattern observed (Table 4).

In several of the cases, simultaneous specimens were available from different body locations. In all of these pairs/sets, the same genotypes were observed, but with differences in the ratio of mutant versus wild type in patients harbouring quasispecies. Other studies have identified D222G quasispecies mainly in endotracheal aspirate or broncheoalveolar lavage (BAL) samples and less frequently in nasopharyngeal aspirate samples $[12,14,20]$. This discrepancy could be due to the use of different analytical methods. Lower rates of mutant versus wild type in nasal swabs may not have been revealed by conventional sequencing. This was demonstrated by Baldanti et al. [14] in D222G/N cases with available paired nasal swabs and BAL samples, the authors found $\mathrm{D} 222 \mathrm{G} / \mathrm{N}$ in only one of four cases using direct sequencing, but this proportion increased to three of four cases using clonal analysis. From our study, we cannot exclude the possibility that the occurrence of the mutation as a quasispecies, together with the wild-type, is due to a complementary function of the wild-type. This phenomenon might change if the mutant virus were to develop another fitness-compensatory mutation that permits the mutant to replicate and spread in pure form. This possibility needs to be further studied.

In addition to its possible biological importance the fact that the majority of the cases with $222 \mathrm{G}$ mutants carried a mixture of $222 \mathrm{D}$ - and $222 \mathrm{G}$-encoding viral genomes, usually with predominance of the wild-type 222D, makes it likely that many influenza $A\left(\mathrm{H}_{1} \mathrm{~N}_{1}\right)$ pdmo9 cases worldwide carrying D222G mutant viruses could have been missed in analyses that are not sensitive to minor nucleic acid species or where only the majority nucleotide is recorded in the published sequence.

Selleri et al. analysed influenza $A\left(\mathrm{H}_{1} \mathrm{~N}_{1}\right)$ pdmo9 viral quasispecies and the polymorphism at codon 222 by ultra-deep pyrosequencing [28]. Codon 222 polymorphism was detected in $40.7 \%$ of patients by ultra-deep pyrosequencing and in only $7.1 \%$ by conventional sequencing. They found that the frequency of polymorphism was significantly higher in samples collected from patients with severe manifestations than in those patients with moderate-mild manifestations. The D222G/N/A mutations were detected as either minor or predominant variants only in severe cases, whereas D222E was equally represented in severe and moderate-mild infections.

The question whether the presence of mutant viruses in lower airways is underestimated due to lack of sampling in the lower respiratory tract was investigated by Baldanti et al. [14 ] paired nasal swabs and BAL samples from patients admitted to intensive care units for mechanical ventilation or extracorporeal membrane oxygenation were compared with samples from patients with pneumonia not requiring mechanical ventilation and from community patients. By combining data from nasal swabs and BAL samples, the frequency of $\mathrm{D} 222 \mathrm{G} / \mathrm{N}$ mutants in patients with severe infections increased to $43 \%$, as compared with $7.8 \%$ and $0 \%$ in patients with moderate and mild infections, respectively [14]. Baldanti et al. also showed that the viral RNA levels were significantly higher in BAL samples than those in nasal swabs [14]. Piralla et al. described the same finding, suggesting higher virus replication in the lower respiratory tract [20].

Watanabe et al. have characterised two of the Norwegian virus isolates included in our study, namely $A /$ Norway/3568/2009 (Norway3568) and A/ Norway/3487-2/2009 (Norway3487) [34]. The viruses were isolates from a fatal case (Norway3487) and a mild case (Norway3568): the viruses differ by only 10 amino acids and none of the amino acid changes known to affect virulence were found in PB2, PB1-F2, $\mathrm{HA}$, or NS1, except for an amino acid change to $222 \mathrm{G}$ in $\mathrm{HA}_{1}$, in Norway3487. More efficient viral replication in cultured cells and delayed virus clearance from ferret respiratory organs was observed for Norway3487 virus (isolated from a severe case), as compared with Norway3568 (isolated from a mild case). To some extent, Norway3487 virus caused more severe lung damage in non-human primates than did Norway3568 virus. Moreover, the authors found that PB2 derived from Norway3487 contributed to higher polymerase activity, possibly leading to more efficient viral replication in vitro and in vivo, which in turn also could play a role in the increased lung damage.

In our analysis, all cases with detectable $222 \mathrm{G}$ mutant viruses had severe illness and the prevalence of $222 \mathrm{G}$ increased with the degree of severe outcome. If the conditions for virus growth in lower airways are favourable to $222 \mathrm{G}$ mutants and the likelihood of upgrowth of mutant virus increases with duration of infection, it follows that individuals who fail to limit infection to upper airways and fail to eliminate the infection rapidly stand at greater risk of acquiring mutant viruses. Regardless 
of virulence, such a mechanism may contribute to the observed pattern of mutants being found primarily in severe cases. However, if the mutant viruses are also more virulent, an increased probability of emergence in patients who already have a long-lasting infection involving the lower respiratory tract probably constitutes a vicious circle phenomenon, which underscores the importance of treatment that helps persons with elevated risk to clear the infection rapidly.

The concept of $\mathrm{D} 222 \mathrm{G}$ being a determinant of virulence is supported by a growing body of evidence from in vitro and animal studies including non-human primates [36-45]. Increased tropism of D222G mutant virus for type II pneumocytes [44] may result in more efficient infection, reducing the availability of progenitor cells for essential lung functions and regeneration and thus leading to severe pulmonary impairment. Increased viral titres in the lungs also trigger stronger inflammatory responses, augmenting tissue damage and delaying healing in the infected lungs [44].

While one instance of transmission of $222 \mathrm{G}$ mutant virus has been documented [9], the transmitted virus in this case had acquired an additional mutation, ( $\left.\mathrm{G}_{155} \mathrm{E}\right)$ that may have counteracted the putative $222 \mathrm{G}$-induced receptor-binding changes [46] and there are no indications that effective sustained transmission has taken place. In our data set, one of the patients with mutant viruses was the likely source of infection of a healthcare worker. However, this occurred early in the course of illness: virus from an early specimen, as well as the virus collected from the healthcare worker, was wild type.

In light of the fact that $222 \mathrm{G}$ mutant viruses are and remain substantially less transmissible than corresponding wild-type viruses, their immediate public health impact is limited to the individual cases in whom such mutants occur and the fact that they may possibly contribute to the severity of illness. Similar to the apparent situation with avian influenza $A\left(\mathrm{H}_{5} \mathrm{~N}_{1}\right)$ virus infection in humans, tropism of $222 \mathrm{G}$ mutant viruses for lung cells may contribute to both increased virulence and impaired transmissibility, which may thus be linked traits [47]. On the other hand, when the $\mathrm{H} 275 \mathrm{Y}$ neuraminidase mutation conferring oseltamivir resistance in seasonal influenza $A\left(\mathrm{H}_{1} \mathrm{~N}_{1}\right)$ viruses was first identified, this mutation also correlated with impaired viral fitness [48], a situation that was abruptly changed with the global emergence of highfitness resistant viruses during the 2007/08 influenza season [49]. Similarly, further adaption of the newly emerged $A\left(\mathrm{H}_{1} \mathrm{~N}_{1}\right)$ pdmog virus to humans as host species may conceivably lead to compensatory mutations that render the $222 \mathrm{G}$ mutants more transmissible, or lead to other changes that influence pathogenicity. The evolution of these viruses therefore needs to be closely monitored in a framework that ensures that virological and clinical data are taken into account.
Acknowledgments

We gratefully acknowledge the essential contributions of primary diagnostic laboratories, clinicians and pathologists in making virus-containing materials and the relevant patient information available to us. We also acknowledge the Department for Infectious Disease Epidemiology, Norwegian Institute of Public Health (NIPH) for invaluable help in supplying the clinical data on many of the fatal and intensive care cases. We would like to thank Jan Oksnes, Department of Bacteriology and Immunology, NIPH, as well as Torstein Aune, Hilde Elshaug, Valentina Johansen, Anne Marie Lund, Grethe Hermansen Krogh, Marianne Morken and Remilyn Ramos-Ocao, Department of Virology, NIPH, for excellent technical assistance.

\section{References}

1. Echevarría-Zuno S, Mejía-Aranguré JM, Mar-Obeso AJ, GrajalesMuñiz C, Robles-Pérez E, González-León M, et al. Infection and death from influenza $A \mathrm{H}_{1} \mathrm{~N}_{1}$ virus in Mexico: a retrospective analysis. Lancet. 2009;374(9707):2072-9.

2. World Health Organization (WHO). Clinical management of human infection with pandemic $\left(\mathrm{H}_{1} \mathrm{~N}_{1}\right)$ 2009: revised guidance. Geneva: WHO; November 2009. Available from: http:// www.who.int/csr/resources/publications/swineflu/clinical_ management/en/index.html

3. van den Brand JM, Stittelaar KJ, van Amerongen G, Rimmelzwaan GF, Simon J, de Wit E, et al. Severity of pneumonia due to new $\mathrm{H}_{1} \mathrm{~N}_{1}$ influenza virus in ferrets is intermediate between that due to seasonal $\mathrm{H}_{1} \mathrm{~N}_{1}$ virus and highly pathogenic avian influenza $\mathrm{H}_{5} \mathrm{~N}_{1}$ virus. J Infect Dis. 2010;201(7):993-9.

4. Stevens J, Blixt O, Glaser L, Taubenberger JK, Palese P, Paulson $J C$, et al. Glycan microarray analysis of the hemagglutinins from modern and pandemic influenza viruses reveals different receptor specificities. J Mol Biol. 2006;355(5):1143-55.

5. World Health Organization (WHO). Public health significance of virus mutation detected in Norway. Pandemic (H1N1) 2009 briefing note 17. Geneva: WHO; 20 November 2009. Available from: http://www.who.int/csr/disease/swineflu/notes/ briefing_20091120/en/

6. Preliminary review of $\mathrm{D} 222 \mathrm{G}$ amino acid substitution in the haemagglutinin of pandemic influenza $A\left(\mathrm{H}_{1} \mathrm{~N}_{1}\right) 2009$ viruses. Wkly Epidemiol Rec. 2010;85(4):21-2.

7. Kilander A, Rykkvin R, Dudman SG, Hungnes O. Observed association between the HA1 mutation D222G in the 2009 pandemic influenza $A\left(\mathrm{H}_{1} \mathrm{~N}_{1}\right)$ virus and severe clinical outcome, Norway 2009-2010. Euro Surveill. 2010;15(9):pii=19498. Available from: http://www.eurosurveillance.org/ViewArticle. aspx?Articleld $=19498$

8. Antón A, Marcos MA, Martinez MJ, Ramón S, Martínez A Cardeñosa N, et al. D225G mutation in the hemagglutinin protein found in 3 severe cases of 2009 pandemic influenza $A$ $\left(\mathrm{H}_{1} \mathrm{~N}_{1}\right)$ in Spain. Diagn Microbiol Infect Dis. 2010;67(2):207-8.

9. Puzelli S, Facchini M, Spagnolo D, De Marco MA, Calzoletti $\mathrm{L}$, Zanetti A, et al. Transmission of hemagglutinin D222G mutant strain of pandemic $\left(\mathrm{H}_{1} \mathrm{~N}_{1}\right) 2009$ virus. Emerg Infect Dis. 2010;16(5):863-5.

10. Miller RR, MacLean AR, Gunson RN, Carman WF. Occurrence of haemagglutinin mutation D222G in pandemic influenza $\mathrm{A}\left(\mathrm{H}_{1} \mathrm{~N}_{1}\right)$ infected patients in the West of Scotland, United Kingdom, 2009-10. Euro Surveill. 2010;15(16):pii=19546. Available from: http://www.eurosurveillance.org/ViewArticle. aspx?Articleld $=19546$

11. Wang B, Dwyer DE, Soedjono M, Shi H, Matlho K, Ratnamohan $M$, et al. Evidence of the circulation of pandemic influenza ( $\left.\mathrm{H}_{1} \mathrm{~N}_{1}\right) 2009$ with $\mathrm{D} 222 \mathrm{D} / \mathrm{G} / \mathrm{N} / \mathrm{S}$ hemagglutinin polymorphisms during the first wave of the 2009 influenza pandemic. J Clin Virol. 2011;52(4):304-6.

12. Chen H, Wen X, To KK, Wang P, Tse H, Chan JF, et al. Quasispecies of the D225G substitution in the hemagglutinin of pandemic influenza $A\left(\mathrm{H}_{1} \mathrm{~N}_{1}\right) 2009$ virus from patients with severe disease in Hong Kong, China. J Infect Dis. 2010;201(10):1517-21.

13. Mak GC, Au KW, Tai LS, Chuang KC, Cheng KC, Shiu TC, et al. Association of $\mathrm{D} 222 \mathrm{G}$ substitution in haemagglutinin of 2009 pandemic influenza $\mathrm{A}\left(\mathrm{H}_{1} \mathrm{~N}_{1}\right)$ with severe disease. Euro Surveill. 2010;15(14):pii=19534. Available from: http://www. eurosurveillance.org/ViewArticle.aspx?Articleld=1953

14. Baldanti F, Campanini G, Piralla A, Rovida F, Braschi A, Mojoli $F$, et al. Severe outcome of influenza $A / \mathrm{H}_{1} \mathrm{~N}_{1} /$ ogv infection 
associated with $222 \mathrm{G} / \mathrm{N}$ polymorphisms in the haemagglutinin: a multicentre study. Clin Microbiol Infect. 2011;17(8):1166-9.

15. Melidou A, Gioula G, Exindari M, Chatzidimitriou D, Diza E, Malisiovas N. Molecular and phylogenetic analysis of the haemagglutinin gene of pandemic influenza $\mathrm{H}_{1} \mathrm{~N}_{1} 2009$ viruses associated with severe and fatal infections. Virus Res. 2010;151(2):192-9.

16. Ikonen N, Haanpää M, Rönkkö E, Lyytikäinen O, Kuusi M, Ruutu $\mathrm{P}$, et al. Genetic diversity of the 2009 pandemic influenza $\mathrm{A}\left(\mathrm{H}_{1} \mathrm{~N}_{1}\right)$ viruses in Finland. PLoS One. 2010;5(10):e13329.

17. Shikov AN, Sementsova AO, Demina OK, Sergeev AA, Berillo SA, Sergeeva EI, et al. [Genetic variability of isolates of pandemic influenza $A$ virus $\mathrm{H}_{1} \mathrm{~N}_{1}$ isolated in Russia in 2009]. Mol Gen Mikrobiol Virusol. 2011;(4)23-9. Russian.

18. El Moussi A, Ledesma J, Ben Hadj Kacem MA, Pozo F, Cuevas MT, Hamdoun M, et al. Haemagglutinin D222G mutation found in a fatal case of pandemic ( $\left.\mathrm{H}_{1} \mathrm{~N}_{1}\right)$ flu in Tunisia. Arch Virol. 2012;157(9):1813-4

19. Malato L, Llavador V, Marmier E, Youssef J, Balick WC, Roze $\mathrm{H}$, et al. Pandemic influenza $A\left(\mathrm{H}_{1} \mathrm{~N}_{1}\right)$ 2009: molecular characterisation and duration of viral shedding in intensive care patients in Bordeaux, south-west France, May 2009 to January 2010. Euro Surveill. 2011;16(4):pii=19776. Available from: http://www.eurosurveillance.org/ViewArticle. aspx?Articleld $=1977$

20. Piralla A, Pariani E, Rovida F, Campanini G, Muzzi A, Emmi V, et al. Segregation of virulent influenza $A\left(\mathrm{H}_{1} \mathrm{~N}_{1}\right)$ variants in the lower respiratory tract of critically ill patients during the 20102011 seasonal epidemic. PLoS One. 2011;6(12):e28332.

21. Potdar VA, Chadha MS, Jadhav SM, Mullick J, Cherian SS, Mishra AC. Genetic characterization of the influenza A pandemic $\left(\mathrm{H}_{1} \mathrm{~N}_{1}\right) 2009$ virus isolates from India. PLoS One. 2010;5(3):e9693.

22. Tse H, To KK, Wen X, Chen H, Chan KH, Tsoi HW, et al. Clinical and virological factors associated with viremia in pandemic influenza $A / \mathrm{H}_{1} \mathrm{~N}_{1} / 2009$ virus infection. PLoS One. 2011;6(9):e22534.

23. Houng HS, Garner J, Zhou Y, Lyons A, Kuschner R, Deye G, et al. Emergent 2009 influenza $\mathrm{A}\left(\mathrm{H}_{1} \mathrm{~N}_{1}\right)$ viruses containing $\mathrm{HA}$ D222N mutation associated with severe clinical outcomes in the Americas. J Clin Virol. 2012;53(1):12-5.

24. Yasugi M, Nakamura S, Daidoji T, Kawashita N, Ramadhany R, Yang CS, et al. Frequency of D222G and Q223R hemagglutinin mutants of pandemic $\left(\mathrm{H}_{1} \mathrm{~N}_{1}\right) 2009$ influenza virus in Japan between 2009 and 2010. PLoS One. 2012;7(2):e30946.

25. Nakajima N, Sato Y, Katano H, Hasegawa H, Kumasaka T, Hata $\mathrm{S}$, et al. Histopathological and immunohistochemical findings of 20 autopsy cases with $2009 \mathrm{H}_{1} \mathrm{~N}_{1}$ virus infection. Mod Pathol. 2012;25(1):1-13.

26. Alonso $M$, Rodríguez-Sánchez B, Giannella $M$, Catalán $P$, Gayoso J, López Bernaldo de Quirós JC, et al. Resistance and virulence mutations in patients with persistent infection by pandemic 2009 A/H1N1 influenza. J Clin Virol. 2011;50(2):114-8.

27. Drews SJ, Pabbaraju K, Wong S, Tokaryk KL, May-Hadford J, Lee B, et al. Surveillance of autopsy cases for D222G substitutions in haemagglutinin of the pandemic $\left(\mathrm{H}_{1} \mathrm{~N}_{1}\right) 2009$ virus in Alberta, Canada. Clin Microbiol Infect. 2011;17(4):582-4.

28. Selleri M, Piralla A, Rozera G, Giombini E, Bartolini B, Abbate , et al. Detection of hæmagglutinin D222 polymorphism in influenza $A\left(\mathrm{H}_{1} \mathrm{~N}_{1}\right)$ pdmog-infected patients by ultradeep pyrosequencing. Clin Microbiol infect. 2012 10.1111/ j1469-0691.2012.03984.X

29. World Health Organization (WHO). Sequencing primers and protocol. Geneva: WHO; 12 May 2009. Available from: http://www.who.int/csr/resources/publications/swineflu/ sequencing_primers/en/index.html

30. World Health Organization (WHO). Protocol No.2: one step conventional RT-PCR for pandemic $\left(\mathrm{H}_{1} \mathrm{~N}_{1}\right) 2009$ HA gene. In: WHO information for laboratory diagnosis of pandemic $\left(\mathrm{H}_{1} \mathrm{~N}_{1}\right) 2009$ virus in humans - revised. Geneva: WHO; 23 November 2009. p. 11. Available from: http://www.who. int/csr/resources/publications/swineflu/WHO_Diagnostic RecommendationsH1N1_20090521.pdf

31. Lackenby A, Democratis J, Siqueira MM, Zambon MC. Rapid quantitation of neuraminidase inhibitor drug resistance in influenza virus quasispecies. Antivir Ther. 2008;13(6):809-20.

32. Felsenstein J. PHYLIP (Phylogeny Inference Package) version 3.5C. Seattle: University of Washington; 1993. Available from: http://cmgm.stanford.edu/phylip/

33. Tamura K, Peterson D, Peterson N, Stecher G, Nei M, Kumar S. MEGA5: molecular evolutionary genetics analysis using maximum likelihood, evolutionary distance, and maximum parsimony methods. Mol Biol Evol. 2011;28(10):2731-9.

34. Wilking H, Buda S, von der Lippe E, Altmann D, Krause G, Eckmanns T, et al. Mortality of 2009 pandemic influenza
$A\left(H_{1} N_{1}\right)$ in Germany. Euro Surveill. 2010;15(49):pii=19741. Available from: http://www.eurosurveillance.org/ViewArticle. aspx?Articleld $=19741$

35. Ramadhany R, Yasugi M, Nakamura S, Daidoji T, Watanabe Y, Takahashi K, et al. Tropism of pandemic 2009 H1N1 influenza A virus. Front Microbiol. 2012;3:128.

36. Watanabe T, Imai M, Watanabe S, Shinya K, Hatta M, Li C, et al. Characterization in vitro and in vivo of pandemic $\left(\mathrm{H}_{1} \mathrm{~N}_{1}\right) 2009$ viruses isolated from patients. J Virol. 2012;86(17):9361-8.

37. Abed Y, Pizzorno A, Hamelin ME, Leung A, Joubert P, Couture C, et al. The 2009 pandemic $\mathrm{H}_{1} \mathrm{~N}_{1} \mathrm{D}_{222} \mathrm{G}$ hemagglutinin mutation alters receptor specificity and increases virulence in mice but not in ferrets. J Infect Dis. 2011;204(7):1008-16.

38. Belser JA, Jayaraman A, Raman R, Pappas C, Zeng H, Cox NJ, et al. Effect of $\mathrm{D} 222 \mathrm{G}$ mutation in the hemagglutinin protein on receptor binding, pathogenesis and transmissibility of the 2009 pandemic $\mathrm{H}_{1} \mathrm{~N}_{1}$ influenza virus. PLoS One. 2011;6(9):e25091.

39. Chutinimitkul S, Herfst S, Steel J, Lowen AC, Ye J, van van Riel D, et al. Virulence-associated substitution D222G in the hemagglutinin of 2009 pandemic influenza $A\left(\mathrm{H}_{1} \mathrm{~N}_{1}\right)$ virus affects receptor binding. J Virol. 2010;84(22):11802-13.

40. Ilyushina NA, Khalenkov AM, Seiler JP, Forrest HL, Bovin $\mathrm{NV}$, Marjuki $\mathrm{H}$, et al. Adaptation of pandemic $\mathrm{H}_{1} \mathrm{~N}_{1}$ influenza viruses in mice. J Virol. 2010;84(17):8607-16.

41. Liu Y, Childs RA, Matrosovich T, Wharton S, Palma AS, Chai W, et al. Altered receptor specificity and cell tropism of D222G hemagglutinin mutants isolated from fatal cases of pandemic $\mathrm{A}\left(\mathrm{H}_{1} \mathrm{~N}_{1}\right) 2009$ influenza virus. J Virol. 2010;84(22):12069-74.

42. Memoli MJ, Bristol T, Proudfoot KE, Davis AS, Dunham EJ, Taubenberger JK. In vivo evaluation of pathogenicity and transmissibility of influenza $\mathrm{A}\left(\mathrm{H}_{1} \mathrm{~N}_{1}\right)$ pdmog hemagglutinin receptor binding domain 222 intrahost variants isolated from a single immunocompromised patient. Virology. 2012;428(1):21-9.

43. Seyer R, Hrincius ER, Ritzel D, Abt M, Mellmann A, Marjuki $\mathrm{H}$, et al. Synergistic adaptive mutations in the hemagglutinin and polymerase acidic protein lead to increased virulence of pandemic $2009 \mathrm{H}_{1} \mathrm{~N}_{1}$ influenza A virus in mice. J Infect Dis. 2012;205(2):262-71

44. Watanabe T, Shinya K, Watanabe S, Imai M, Hatta M, Li C, et al. Avian-type receptor-binding ability can increase influenza virus pathogenicity in macaques. J Virol. 2011;85(24):13195-203.

45. Ye J, Sorrell EM, Cai Y, Shao H, Xu K, Pena L, et al. Variations in the hemagglutinin of the $2009 \mathrm{H}_{1} \mathrm{~N}_{1}$ pandemic virus: potential for strains with altered virulence phenotype? PLoS Pathog. 2010;6(10):e1001145

46. Takahashi T, Hashimoto A, Maruyama M, Ishida $\mathrm{H}$, Kiso M, Kawaoka Y, et al. Identification of amino acid residues of influenza $A$ virus $\mathrm{H}_{3}$ HA contributing to the recognition of molecular species of sialic acid. FEBS Lett. 2009;583(19):3171-4.

47. Shinya K, Ebina M, Yamada S, Ono M, Kasai N, Kawaoka Y. Avian flu: influenza virus receptors in the human airway. Nature. 2006;440(7083):435-6.

48. Ives JA, Carr JA, Mendel DB, Tai CY, Lambkin R, Kelly L, et al. The $\mathrm{H}_{2} 74 \mathrm{Y}$ mutation in the influenza $\mathrm{A} / \mathrm{H}_{1} \mathrm{~N}_{1}$ neuraminidase active site following oseltamivir phosphate treatment leave virus severely compromised both in vitro and in vivo. Antiviral Res. 2002;55(2):307-17.

49. Meijer A, Lackenby A, Hungnes O, Lina B, van der Werf S, Schweiger $B$, et al. Oseltamivir-resistant influenza virus $A$ ( $\left.\mathrm{H}_{1} \mathrm{~N}_{1}\right)$, Europe, 2007-08 season. Emerg Infect Dis. 2009 Apr;15(4):552-60. 